\title{
Prognostic Value Of The Preoperative Neutrophil To Lymphocyte Ratio In Patients With Sinonasal Squamous Cell Carcinoma
}

This article was published in the following Dove Press journal: Cancer Management and Research

\author{
Bing Zhong \\ Di Deng \\ Jin-Tao Du \\ Fei Chen (ID) \\ Ya-Feng Liu \\ Shi-Xi Liu (D)
}

Department of Otorhinolaryngology Head and Neck Surgery, West China Hospital, Sichuan University, Chengdu, People's Republic of China
Correspondence: Shi-Xi Liu

Department of Otorhinolaryngology Head and Neck Surgery, West China Hospital, Sichuan University, 37 Guo Xue

Xiang, Chengdu 6I004I, Sichuan

Province, People's Republic of China

Tel +86 I898060I4III

Fax +862885423627

Email Isxent@163.com
Objective: This study explored the effectiveness of a new inflammatory prognostic system, using preoperative neutrophil to lymphocyte ratio (NLR) to predict the postoperative survival rate of patients with sinonasal squamous cell carcinoma (SSCC).

Methods: Patients diagnosed with SSCC who undergone surgically treated without neoadjuvant therapy were included in the study between May 2008 and October 2017. Preoperative NLR is defined as: preoperative neutrophil/postoperative lymphocyte ratio. The prognostic value was uncovered by univariate and multivariate Cox hazards analysis.

Results: A total of 147 patients were included in this study. Through the multivariate analysis, pathological T stage (hazard ratio [HR] 1.719, confidence interval [CI] 1.277-3.642, $\mathrm{p}<0.001$ ), pathological N stage (HR 1.344, 95\% CI 1.015-2.776, $<<0.001$ ), and preoperative NLR (HR 1.579, 95\% CI 1.217-3.092, $\mathrm{p}=0.002$ ) were independent risk factor for overall survival (OS). Pathological T stage (HR 1.835, 95\% CI 1.141-3.132, <0.001), pathological $\mathrm{N}$ stage (HR 1.281, 95\% CI 1.169-2.476, $\mathrm{p}<0.001$ ), and preoperative NLR (HR 1.688, 95\% CI 1.162-3.363, p p $<0.001)$ were also independently associated with disease-free survival (DFS). Pathological T stage (HR $\mathrm{p}<0.001,95 \%$ CI 1.537-3.021, $\mathrm{p}<0.001$ ), pathological N stage (HR1.571, 95\% CI 1.157-2.258, p<0.001), and preoperative NLR (HR 1.509, 95\% CI 1.153-3.104, $\mathrm{p}=0.001$ ) were independent risk factors for disease-specific survival (DSS). Conclusion: The preoperative NLR is considered to be a useful predictor of postoperative survival in SSCC patients.

Keywords: sinonasal carcinoma, albumin-to-globulin ratio, patients, risk factor, survival

\section{Introduction}

Among head and neck tumors, the incidence and mortality of SSCC are relatively high, among which the most common type is squamous cell carcinoma. ${ }^{1,2}$ Difficult anatomic localization and early lymph node metastasis determine poor prognosis of SSCC. Endoscopic resection and lateral rhinotomy are still the main surgical methods, but complex anatomy and bone obstruction make complete resection of SSCC difficult. ${ }^{3,4}$ Stratified management of SSCC patients is of great significance for selecting treatment mode. Therefore, using a simple, convenient and inexpensive index to predict the prognosis of SSCC patients is of great significance for the determination of clinical treatment regiments.

In recent years, more and more evidence show that blood index has a definite significance in predicting the prognosis of tumor patients. Elevated levels of neutrophils are considered a marker of local and systemic inflammation, and their 
production of cytokines and angiogenic factors significantly promotes tumor development. ${ }^{5,6}$ As an important defense of the immune system, lymphocytes are related to the body's immune surveillance. ${ }^{7,8}$ Preoperative NLR represents the preoperative neutrophil/postoperative lymphocyte ratio, maybe more helpful for patients with tumor prognosis prediction. Previous studies have shown that preoperative elevation of NLR is an independent predictor of poor prognosis in non-metastatic papillary renal cell carcinoma. ${ }^{9}$ In a 16-year follow-up study of 527,124 Korean adults, the NLR was independently associated with an increased risk of lung cancer mortality. ${ }^{10}$ However, the predictive role of NLR in SSCC has been unclear due to the lack of literature. Since NLR is an important prognostic factor for multiple tumors, we hypothesized the indicator is also associated with the prognosis of SSCC. The purpose of this study was to evaluate the predictability of preoperative NLR to long-term mortality after the operation of SSCC patients.

\section{Materials And Methods}

\section{Patients}

The study was approved by the ethics committee of the West China Hospital of Sichuan University and has been performed in accordance with the ethical standards laid down in an appropriate version of the Declaration of Helsinki (as revised in Brazil 2013). Patients who only underwent tumor resection at the hospital between May 2008 and October 2017 took part in this study. Postoperative pathological diagnosis was SSCC. The exclusion criteria are as follows: connective tissue disease or other diseases that affect blood cell lines; patients who stopped treatment during hospitalization; patients with liver impairment; and patients receiving preoperative antitumor therapy (including antitumor therapy). All patients underwent blood cell tests, coagulation, nasal endoscopy, abdominal ultrasonography, head and neck computed tomography or magnetic resonance imaging and chest radiography 3 days before was given a form of treatment. If multiple tests are performed, the results of the first test will be the standard. Preoperative NLR is meant by preoperative neutrophil/preoperative lymphocyte.

\section{Follow-Up}

First follow-up was conducted in the first month after surgically treated SSCC and every three months. Postoperative items include blood cell detection, coagulation, electron fiber laryngoscope, abdominal ultrasound, head and neck magnetic resonance imaging (MRI) or computed tomography (CT), and chest CT. A positive nasal endoscopic biopsy suggested recurrence.

\section{Statistical Methods}

For statistical analysis, statistical Package for social sciences 21(SPSS21) (SPSS Inc., Chicago, IL, USA) was utilized. This is a retrospective chart review. The cut-off point for preoperative NLR was determined by the median value. Variables with a $p$ value $<0.05$ in the univariate analyses were selected for multivariate analyses by Cox regression. The survival curve was estimated by Kaplan-Meier analysis, and the log rank test was used to examine the significance of differences in survival distribution between groups. $\mathrm{P}<0.05$ was considered statistically significant.

\section{Results}

\section{Patient Characteristics}

Of the 147 patients enrolled, 123 were men, and 24 were women. The age was $61.33 \pm 13.31$ years. As showed in Table 1, there were 21 non-smokers and 126 smokers and with an average body mass index (BMI) of $24.13 \pm$ $3.31 \mathrm{~kg} / \mathrm{m}^{2}$. The number of patients with tumor size $<$ $2.5 \mathrm{~cm}$ and $\geq 2.5 \mathrm{~cm}$ was 89 and 58 , respectively. Three pathological types (G1, G2 and, G3) numbers were 31, 84 and 32, respectively. Four pathological types (T1, T2, $\mathrm{T} 3$ and T4) numbers were 21, 61, 33 and 32, respectively. There were 51 patients with negative pathological $\mathrm{N}$ stage (NX, N0) and 96 patients with positive pathological $\mathrm{N}$ stage (N1, N2, N3). In all, 44 patients received endoscopic surgery, while 103 received nasal endoscopic combined with lateral rhinotomy (Table 1). The duration of follow up for the survivors was $39.21 \pm 15.36$ months with a mean duration of overall survival of $38.44 \pm 14.69$ months, disease free survival of $38.13 \pm 14.04$ months and disease specific survival of $37.47 \pm 13.15$ months. 32 patients received radiotherapy and 14 patients received chemotherapy. 68 patients suffered recurrence (46.3\%) and 83 patients died during follow-up (56.5\%). The 5 -year OS, DSS, and DFS rates for all patients were $59.4 \%, 61.3 \%$, and $52.8 \%$, respectively (Figure 1).

\section{Risk Factors Associated With OS}

Univariate Cox hazards analysis showed that smoking status, BMI, histological type, pathological $\mathrm{T}$ stage, pathological $\mathrm{N}$ stage, and preoperative NLR were 
Table I Patient Characteristics

\begin{tabular}{|c|c|}
\hline Varibles & No./Mean \pm SD \\
\hline Age (years) & $61.33 \pm \mid 3.31$ \\
\hline \multicolumn{2}{|l|}{ Gender } \\
\hline Male & 123 \\
\hline Female & 24 \\
\hline \multicolumn{2}{|l|}{ Smoking status } \\
\hline Never smoked & 21 \\
\hline Smoked in past & 126 \\
\hline BMI $\left(\mathrm{kg} / \mathrm{m}^{2}\right)$ & $24.13 \pm 3.31$ \\
\hline \multicolumn{2}{|l|}{ Tumor size } \\
\hline$<2.5 \mathrm{~cm}$ & 89 \\
\hline$\geq 2.5 \mathrm{~cm}$ & 58 \\
\hline \multicolumn{2}{|l|}{ Histological type } \\
\hline Low & 31 \\
\hline Medium & 84 \\
\hline High & 32 \\
\hline \multicolumn{2}{|l|}{ Pathological T stage } \\
\hline TI & 21 \\
\hline $\mathrm{T} 2$ & 61 \\
\hline T3 & 33 \\
\hline T4 & 32 \\
\hline \multicolumn{2}{|l|}{ Pathological $\mathrm{N}$ stage } \\
\hline Negative (NX, N0) & 51 \\
\hline Positive (NI, N2, N3) & 96 \\
\hline \multicolumn{2}{|l|}{ Surgery } \\
\hline Endoscopic resection & 44 \\
\hline Endoscopic resection + Lateral rhinotomy & 103 \\
\hline \multicolumn{2}{|l|}{ Laboratory } \\
\hline Albumin, g/l & $42.32 \pm 5.43$ \\
\hline Hemoglobin, g/dl & $127.45 \pm 20.56$ \\
\hline White blood cell count, $10^{\wedge} 9 / \mathrm{L}$ & $7.11 \pm 2.98$ \\
\hline Neutrophil count, $10^{\wedge} 9 / \mathrm{L}$ & $4.88 \pm 2.91$ \\
\hline Platelet count, I0^9/L & $229.91 \pm 74.25$ \\
\hline NLR & $4.19 \pm 1.33$ \\
\hline
\end{tabular}

Abbreviations: BMI, Body Mass Index; NLR, neutrophil to lymphocyte ratio.

associated with the OS (Table 2). However, multivariate analysis prompted only pathological $\mathrm{T}$ stage (HR 1.719, CI 1.277-3.642, $\mathrm{p}<0.001$ ), pathological $\mathrm{N}$ stage (HR $1.344,95 \%$ CI $1.015-2.776, \mathrm{p}<0.001$ ), and preoperative NLR (HR 1.579, 95\% CI 1.217-3.092, $\mathrm{p}=0.002$ ) have influence in OS.

\section{Risk Factors Associated With DFS}

Univariate analysis showed that smoking status, BMI, histological type, pathological $\mathrm{T}$ stage, pathological
$\mathrm{N}$ stage, and preoperative NLR may influence DFS of SSCC (Table 3). However, results showed that only the pathological $\mathrm{T}$ stage (HR 1.835, 95\% CI 1.141-3.132, $<0.001$ ), pathological N stage (HR 1.281, 95\% CI 1.169-2.476, $<<0.001$ ), and preoperative NLR (HR 1.688, 95\% CI 1.162-3.363, $\mathrm{p} \mathrm{p}<0.001$ ) have statistical significance in multivariate analysis.

\section{Risk Factors Associated With DSS}

Univariate analysis showed that smoking status, BMI, histological type, pathological $\mathrm{T}$ stage, pathological $\mathrm{N}$ stage, and preoperative NLR may influence DSS of SSCC (Table 4). However, results showed that only pathological T stage (HR $\mathrm{p}<0.001,95 \%$ CI 1.537-3.021, $\mathrm{p}<0.001$ ), pathological $\mathrm{N}$ stage (HR 1.571, 95\% CI 1.157-2.258, $\mathrm{p}<0.001$ ), and preoperative NLR (HR 1.509, 95\% CI 1.153-3.104, $\mathrm{p}=0.001$ ) have statistical significance in multivariate analysis.

\section{Discussion}

As cancer with a very poor prognosis, there is still no treatment that can significantly improve the survival of patients except surgical treatment. ${ }^{11,12}$ It has been reported that SSCC was related to chronic stimulation such as smoking, drinking, and nutritional factors. Although surgery combined with radiotherapy and chemotherapy has been widely used, prolonging the survival of patients with SSCC remains a challenge. Many studies have found that systemic inflammatory response is closely related to the prognosis of patients with various tumors including SSCC, which provides a new basis for the stratified treatment of patients. ${ }^{13,14}$

As a reliable marker of systemic inflammation, the simplicity and convenience of neutrophils and lymphocytes make them easy to detect in terms of their ability to reflect the immune state of the body. ${ }^{15,16}$ The inflammatory state of the body has been shown to be closely related to pathological processes such as tumorigenesis, angiogenesis, apoptosis inhibition, and distant metastasis, especially in patients with advanced cancer, where changes in inflammatory markers are more closely related to patient survival. ${ }^{17-19}$ Elevated neutrophils may activate and control tumor cell proliferation, angiogenesis, chemokines, and expression of cytokine genes. The reduction of lymphocytes is the manifestation of immune suppression, which is undoubtedly a warning of poor prognosis. ${ }^{17,20}$ Separate use of neutrophils or lymphocytes can not fully reflect the body state of inflammation, immune level and 

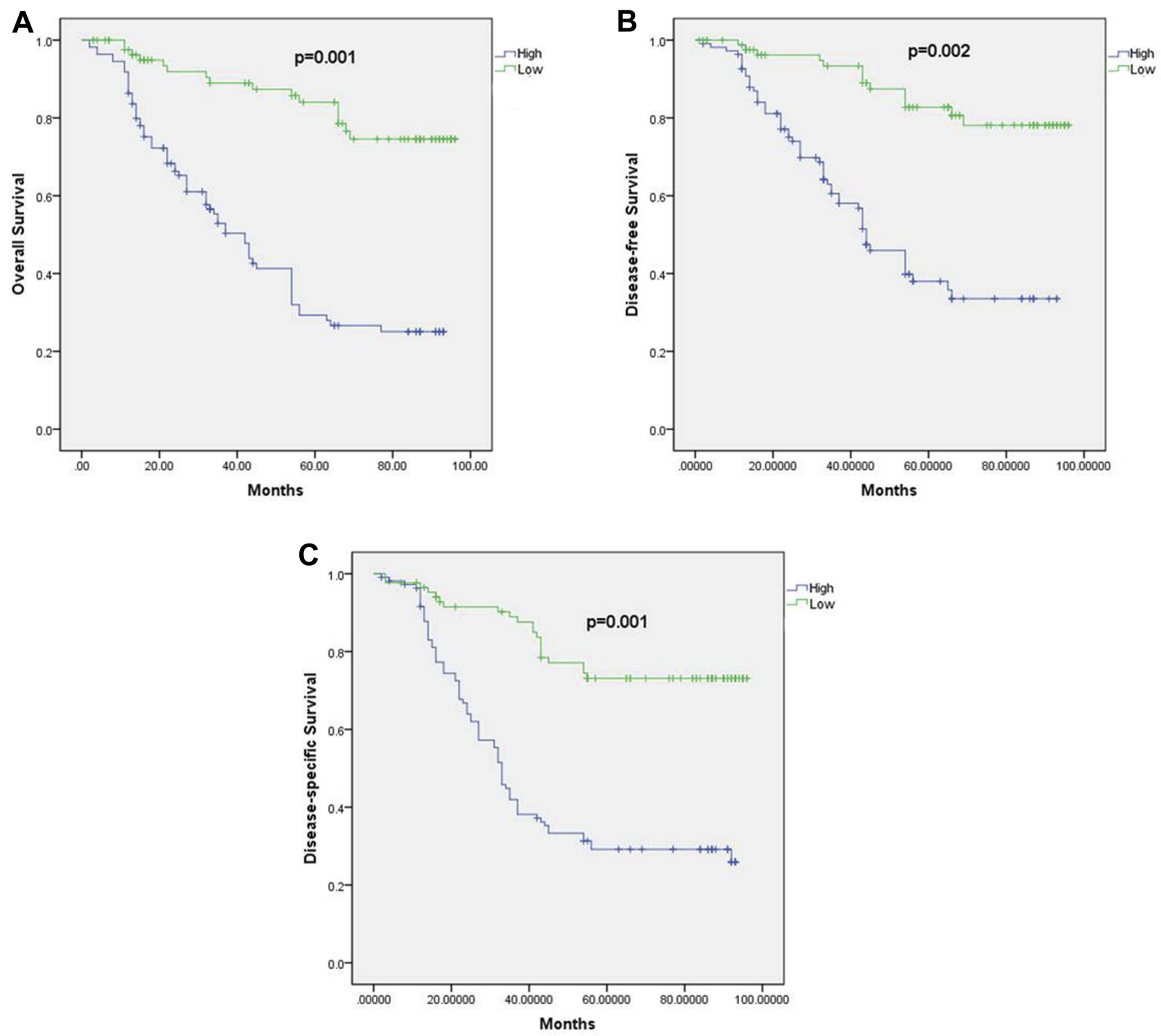

Figure I OS (A), DSS (B) and DFS (C) curves of patients with high NLR versus those with low NLR.

show the progress of tumor. Considering the possible errors in the prediction of patient prognosis using the two indicators alone, NLR may be a better choice.

The inflammatory microenvironment promotes tumor growth and migration, and in turn, tumor cells facilitate the release of inflammatory factors. ${ }^{21,22}$ Activation of inflammatory cytokines, such as interleukin-1, interleukin-6, and tumor necrosis factor-alpha, leads to an increase in neutrophils and lymphocytes. In recent years, many studies have looked at the effects of inflammatory markers in the blood on tumors, and the rising trend in NLR has been shown to increase the risk of death in cancer patients. $^{23,24}$ We used the median preoperative NLR to determine its truncation value, and the results showed that the survival rate of patients with low preoperative NLR was significantly higher than that of patients with high preoperative NLR which consistent with previous studies. Getzler et al found that NLR $>2.5$ is an independent risk factor of non-muscle invasive cancer prognosis, indicating poor recurrence-free survival. ${ }^{25}$ In a retrospective study of 1020 patients with hepatocellular carcinoma in Yang et al, NLR was confirmed as an independent predictor of recurrence after analysis by propensity score matching. ${ }^{17}$ In addition, previous literature also indicated that NLR $>6.875$ was associated with the risk of distant metastasis and death in patients with palatal tonsillar squamous cell carcinoma receiving postoperative intensity modulated radiotherapy. ${ }^{26}$ 
Table 2 Univariate And Multivariate Cox Hazards Analysis For OS In Patients With SSCC

\begin{tabular}{|c|c|c|c|c|}
\hline \multirow[t]{2}{*}{ Varibles } & \multicolumn{2}{|l|}{ Univariate Analysis } & \multicolumn{2}{|c|}{ Multivariate Analysis } \\
\hline & HR (95\% Cl) & p-value & HR(95\% Cl) & p-value \\
\hline $\begin{array}{l}\text { Age (years) } \\
\quad>58 \\
\quad \leq 58\end{array}$ & $\begin{array}{l}\text { I } \\
0.339(0.132-1.627)\end{array}$ & 0.347 & & \\
\hline $\begin{array}{l}\text { Gender } \\
\text { Male } \\
\text { Female }\end{array}$ & I.369(0.594-1.724) & 0.535 & & \\
\hline $\begin{array}{l}\text { Smoking status } \\
\text { Never smoked } \\
\text { Smoked in past }\end{array}$ & $1.209(1.013-1.875)$ & 0.021 & $\begin{array}{l}\text { I } \\
0.935(0.285-1.94 I)\end{array}$ & 0.698 \\
\hline $\begin{array}{l}\mathrm{BMI}\left(\mathrm{kg} / \mathrm{m}^{2}\right) \\
\quad \leq 22.45 \\
>22.45\end{array}$ & $1.209(1.011-2.033)$ & 0.011 & $0.881(0.215-1.228)$ & 0.588 \\
\hline $\begin{array}{l}\text { Tumor size } \\
\leq 2.5 \mathrm{~cm} \\
>2.5 \mathrm{~cm}\end{array}$ & $\mathrm{I} .559(0.433-3.38 \mathrm{I})$ & 0.665 & & \\
\hline $\begin{array}{l}\text { Histological type } \\
\text { High } \\
\text { Medium, low }\end{array}$ & I.756(I.553-2.663) & 0.002 & I.03I(0.484-2.015) & 0.351 \\
\hline $\begin{array}{l}\text { Pathological T stage } \\
\text { TI, T2 } \\
\text { T3, T4 }\end{array}$ & $1.669(1.353-3.664)$ & $<0.001$ & $1.719(1.277-3.642)$ & $<0.001$ \\
\hline $\begin{array}{l}\text { Pathological N stage } \\
\text { Negative(NX, N0) } \\
\text { Positive(NI, N2, N3) }\end{array}$ & I.2। & $<0.001$ & $1.344(1.015-2.776)$ & $<0.001$ \\
\hline $\begin{array}{l}\text { Surgery } \\
\text { Nasal endoscopy } \\
\text { Nasal endoscopy + Lateral rhinotomy } \\
\text { Albumin }(>38.3 / \leq 38.3, g / l) \\
\text { Hemoglobin }(>\mid 28 / \leq 128), g / d l) \\
\text { WBC count, }\left(>8.34 / \leq 8.34,10^{\wedge} 9 / L\right) \\
\text { Neutrophil count, }(>5.44 / \leq 5.44, \text { I0^9/L) } \\
\text { Platelet count, }(>198 / \leq 198, \text { I0^9/L) }\end{array}$ & $\begin{array}{l}\text { I } \\
1.570(0.255-4.114) \\
1.187(0.746-1.665) \\
0.414(0.139-1.439) \\
1.145(0.343-1.549) \\
1.975(0.644-2.988) \\
1.804(0.773-2.191)\end{array}$ & $\begin{array}{l}0.547 \\
0.441 \\
0.571 \\
0.648 \\
0.773 \\
0.761\end{array}$ & & \\
\hline $\begin{array}{l}\text { NLR } \\
\text { High }(\leq 4.25) \\
\operatorname{Low}(>4.25)\end{array}$ & I.888(1.336-3.342) & $<0.001$ & $1.579(1.217-3.092)$ & 0.002 \\
\hline
\end{tabular}

Abbreviations: BMI, Body Mass Index; NLR, neutrophil to lymphocyte ratio.

NLR is a known systemic inflammatory scoring system that plays an important role in systemic inflammation and immune response in tumor growth. ${ }^{27,28}$ Although the predictive value of NLR has been reported in many tumors, its potential mechanism as a prognostic factor remains to be further studied. ${ }^{29}$ In fact, many blood markers have been linked to aggressive and metastatic tumors. As a marker of inflammatory response, NLR is also related to tumor proliferation, invasion, metastasis and drug resistance. ${ }^{30}$ Yoshida et al found that the function of preoperative NLR in predicting disease-free survival of patients with stage I-II rectal cancer was equivalent to pathologic t-category, and lymphatic invasion, which could be an 
Table 3 Univariate And Multivariate Cox Hazards Analysis For DFS In Patients With SSCC

\begin{tabular}{|c|c|c|c|c|}
\hline \multirow[t]{2}{*}{ Varibles } & \multicolumn{2}{|c|}{ Univariate Analysis } & \multicolumn{2}{|c|}{ Multivariate Analysis } \\
\hline & HR (95\% Cl) & p-value & HR (95\% Cl) & p-value \\
\hline $\begin{array}{l}\text { Age (years) } \\
\quad>58 \\
\quad \leq 58\end{array}$ & $\begin{array}{l}\text { I } \\
0.357(0.119-1.510)\end{array}$ & 0.322 & & \\
\hline $\begin{array}{l}\text { Gender } \\
\text { Male } \\
\text { Female }\end{array}$ & $\begin{array}{l}\mathrm{I} \\
1.447(0.699-1.919)\end{array}$ & 0.472 & & \\
\hline $\begin{array}{l}\text { Smoking status } \\
\text { Never smoked } \\
\text { Smoked in past }\end{array}$ & $1.312(1.055-1.967)$ & 0.033 & $\begin{array}{l}\text { I } \\
0.88 I(0.253-\mid .749)\end{array}$ & 0.783 \\
\hline $\begin{array}{l}\mathrm{BMI}\left(\mathrm{kg} / \mathrm{m}^{2}\right) \\
\quad \leq 22.45 \\
>22.45\end{array}$ & $\begin{array}{l}\mathrm{I} \\
\mathrm{I} .371(1.075-1.939)\end{array}$ & 0.025 & $\begin{array}{l}\text { I } \\
0.654(0.197-1.134)\end{array}$ & 0.672 \\
\hline $\begin{array}{l}\text { Tumor size } \\
\quad \leq 2.5 \mathrm{~cm} \\
>2.5 \mathrm{~cm}\end{array}$ & I.479(0.5 I3-3.099) & 0.588 & & \\
\hline $\begin{array}{l}\text { Histological type } \\
\text { High } \\
\text { Medium, low }\end{array}$ & $\begin{array}{l}\mathrm{I} \\
1.667(1.379-2.501)\end{array}$ & 0.014 & $\begin{array}{l}\text { I } \\
1.266(0.57 \mid-2.233)\end{array}$ & 0.516 \\
\hline $\begin{array}{l}\text { Pathological T stage } \\
\text { TI, T2 } \\
\text { T3, T4 }\end{array}$ & I.578(I.362-3.546) & $<0.001$ & $\mathrm{I}$ & $<0.001$ \\
\hline $\begin{array}{l}\text { Pathological N stage } \\
\text { Negative(NX, N0) } \\
\text { Positive(NI, N2, N3) }\end{array}$ & I.365(I.14I-2.388) & $<0.001$ & $1.281(1.169-2.476)$ & $<0.001$ \\
\hline $\begin{array}{l}\text { Surgery } \\
\text { Nasal endoscopy } \\
\text { Nasal endoscopy + Lateral rhinotomy } \\
\text { Albumin }(>38.3 / \leq 38.3, \mathrm{~g} / \mathrm{l}) \\
\text { Hemoglobin }(>128 / \leq 128), \mathrm{g} / \mathrm{dl}) \\
\text { WBC count, }(>8.34 / \leq 8.34, \text { I0^9/L) } \\
\text { Neutrophil count, }\left(>5.44 / \leq 5.44, \text { I } 0^{\wedge} 9 / \mathrm{L}\right) \\
\text { Platelet count, }\left(>198 / \leq 198,10^{\wedge} 9 / \mathrm{L}\right)\end{array}$ & $\begin{array}{l}\text { I } \\
1.257(0.614-3.845) \\
1.219(0.511-1.546) \\
0.452(0.261-1.578) \\
1.274(0.215-1.659) \\
1.845(0.884-2.732) \\
1.633(0.815-2.442)\end{array}$ & $\begin{array}{l}0.589 \\
0.674 \\
0.615 \\
0.463 \\
0.547 \\
0.632\end{array}$ & & \\
\hline $\begin{array}{l}\text { NLR } \\
\qquad \text { High }(\leq 4.25) \\
\operatorname{Low}(>4.25)\end{array}$ & $\begin{array}{l}\mathrm{I} \\
1.763(1.156-3.149)\end{array}$ & $<0.001$ & I $1.688(1.162-3.363)$ & $<0.001$ \\
\hline
\end{tabular}

Abbreviations: BMI, Body Mass Index; NLR, neutrophil to lymphocyte ratio.

independent predictor of tumor recurrence. ${ }^{31}$ In this study, univariate and multivariate analyses indicated that preoperative NLR was an independent predictor of poor prognosis for SSCC, whether in OS, DSS or DFS. Patients in the group with higher preoperative NLR levels had a lower five-year survival rate than those with lower preoperative NLR levels.
This study has some limitations. Firstly, this is a single-center study, which inevitably limits the number of samples. The reliability of our conclusion needs to be confirmed by future multi-center studies. Secondly, we only focused on SSCC, and whether this conclusion is applicable to most patients with head and neck tumors remains to be unclear. In addition, we have only verified 
Table 4 Univariate And Multivariate Cox Hazards Analysis For DSS In Patients With SSCC

\begin{tabular}{|c|c|c|c|c|}
\hline \multirow[t]{2}{*}{ Varibles } & \multicolumn{2}{|l|}{ Univariate Analysis } & \multicolumn{2}{|c|}{ Multivariate Analysis } \\
\hline & HR (95\% Cl) & p-value & HR (95\% Cl) & p-value \\
\hline $\begin{array}{l}\text { Age (years) } \\
\quad>58 \\
\quad \leq 58\end{array}$ & $\begin{array}{l}\text { I } \\
0.436(0.201-1.555)\end{array}$ & 0.498 & & \\
\hline $\begin{array}{l}\text { Gender } \\
\text { Male } \\
\text { Female }\end{array}$ & $1.386(0.721-1.976)$ & 0.562 & & \\
\hline $\begin{array}{l}\text { Smoking status } \\
\text { Never smoked } \\
\text { Smoked in past }\end{array}$ & I.447(1.121-1.998) & 0.027 & $\begin{array}{l}\text { I } \\
0.802(0.3 \mid 4-1.853)\end{array}$ & 0.814 \\
\hline $\begin{array}{c}\mathrm{BMI}\left(\mathrm{kg} / \mathrm{m}^{2}\right) \\
\leq 22.45 \\
>22.45\end{array}$ & I.435(1.028-1.953) & 0.009 & $\begin{array}{l}\text { I } \\
0.774(0.216-1.339)\end{array}$ & 0.737 \\
\hline $\begin{array}{l}\text { Tumor size } \\
\leq 2.5 \mathrm{~cm} \\
>2.5 \mathrm{~cm}\end{array}$ & I.533(0.635-3.205) & 0.625 & & \\
\hline $\begin{array}{l}\text { Histological type } \\
\text { High } \\
\text { Medium, low }\end{array}$ & I.582(1.246-2.672) & 0.036 & I. $.378(0.649-2.546)$ & 0.671 \\
\hline $\begin{array}{l}\text { Pathological T stage } \\
\text { TI, T2 } \\
\text { T3, T4 }\end{array}$ & I.453(1.259-3.133) & $<0.001$ & I.744(I.537-3.02I) & $<0.001$ \\
\hline $\begin{array}{l}\text { Pathological N stage } \\
\text { Negative } \\
\text { Positive }\end{array}$ & I.477(I.204-2.142) & $<0.001$ & $1.57 \mid(1 . \mid 57-2.258)$ & $<0.001$ \\
\hline $\begin{array}{l}\text { Surgery } \\
\text { Nasal endoscopy } \\
\text { Nasal endoscopy + Lateral rhinotomy } \\
\text { Albumin }(>38.3 / \leq 38.3, g / l) \\
\text { Hemoglobin }(>\mid 28 / \leq 128), g / d l) \\
\text { WBC count, }\left(>8.34 / \leq 8.34,10^{\wedge} 9 / \mathrm{L}\right) \\
\text { Neutrophil count, }\left(>5.44 / \leq 5.44, \text { I } 0^{\wedge} 9 / \mathrm{L}\right) \\
\text { Platelet count, }\left(>198 / \leq 198,10^{\wedge} 9 / \mathrm{L}\right)\end{array}$ & $\begin{array}{l}\text { I } \\
I .514(0.735-3.333) \\
\mathrm{I} .646(0.62 \mathrm{I}-\mathrm{I} .879) \\
0.60 \mathrm{I}(0.3 \mathrm{I}-\mathrm{I}-\mathrm{.} 449) \\
\mathrm{I} .443(0.30 \mathrm{I}-\mathrm{I} .877) \\
\mathrm{I} .566(0.642-2.559) \\
\mathrm{I} .753(0.469-2.005)\end{array}$ & $\begin{array}{l}0.663 \\
0.774 \\
0.508 \\
0.516 \\
0.688 \\
0.594\end{array}$ & & \\
\hline $\begin{array}{l}\text { NLR } \\
\text { High }(\leq 4.25) \\
\operatorname{Low}(>4.25)\end{array}$ & I.359(1.033-3.314) & $<0.001$ & $1.509(1.153-3.104)$ & 0.001 \\
\hline
\end{tabular}

Abbreviations: BMI, Body Mass Index; NLR, neutrophil to lymphocyte ratio.

a small number of indicators in the blood, and whether other indicators can better predict the prognosis of SSCC needs to be confirmed by further studies. Moreover, high neutrophil count and low lymphocyte count can both lead to High NLR, leading to inaccurate results. Finally, this study included only patients who underwent surgery. Whether NLR is suitable for SSCC patients with other treatments or surgery combined with other treated requires more research in the future.

In conclusion, our results suggest that preoperative NLR is associated with survival in SSCC patients. As a simple and easy to calculate inflammatory marker, the level of pre-treatment NLR could help us identify highrisk patients with SSCC. 


\section{Ethical Approval And Informed Consent}

All patients provided written informed consent, and that this was conducted in accordance with the Declaration of Helsinki. The study was approved by the ethics committee of the West China Hospital of Sichuan University.

\section{Author Contributions}

All authors made substantial contributions to conception and design, acquisition of data, or analysis and interpretation of data; took part in drafting the article or revising it critically for important intellectual content; gave final approval of the version to be published; and agree to be accountable for all aspects of the work.

\section{Disclosure}

The authors report no conflicts of interest in this work.

\section{References}

1. Mendenhall WM, Amdur RJ, Morris CG, et al. Carcinoma of the nasal cavity and paranasal sinuses. Laryngoscope. 2009;119(5):8 99-906. doi:10.1002/lary.v119:5

2. Kermer C, Poeschl PW, Wutzl A, Schopper C, Klug C, Poeschl E. Surgical treatment of squamous cell carcinoma of the maxilla and nasal sinuses. J Oral Maxillofacial Surg. 2008;66(12):2449-2453. doi:10.1016/j.joms.2008.07.016

3. Dubal PM, Bhojwani A, Patel TD, et al. Squamous cell carcinoma of the maxillary sinus: a population-based analysis. Laryngoscope. 2016;126(2):399-404. doi:10.1002/lary.v126.2

4. Jnanadev KR, Sheethal HS, Suraj HS, Rudresh KB. Management of squamous cell carcinoma of the maxillary sinus. J Oral Maxillofacial Pathol. 2017;21(2):320. doi:10.4103/jomfp.JOMFP_37_17

5. Zhou SL, Yin D, Hu ZQ, et al. A positive feedback loop between cancer stem-like cells and tumor-associated neutrophils controls hepatocellular carcinoma progression. Hepatology. 2019.

6. Song W, Li L, He D, et al. Infiltrating neutrophils promote renal cell carcinoma (RCC) proliferation via modulating androgen receptor (AR) $\rightarrow$ c-Myc signals. Cancer Lett. 2015;368(1):71-78. doi:10. 1016/j.canlet.2015.07.027

7. Noh BJ, Kim JH, Eom DW. Prognostic significance of categorizing gastric carcinoma by PD-L1 expression and tumor infiltrating lymphocytes. Ann Clin Lab Sci. 2018;48(6):695-706.

8. Spector ME, Bellile E, Amlani L, et al. Prognostic value of tumor-infiltrating lymphocytes in head and neck squamous cell carcinoma. JAMA Otolaryngol Head Neck Surg. 2019. doi:10.1001/ jamaoto.2019.2427

9. Tu X, Wang F, Chang T, et al. Predictive value of preoperative neutrophil-to-lymphocyte ratio in non-metastatic papillary renal cell carcinoma patients after receiving curative surgery. Cancer Manag Res. 2019;11:7515-7524. doi:10.2147/CMAR.S211727

10. Kang J, Chang Y, Ahn J, et al. Neutrophil-to-lymphocyte ratio and risk of lung cancer mortality in a low-risk population: a cohort study. Int J Cancer. 2019. doi:10.1002/ijc.v145.12

11. Tiwari RM, Kodaganur GS, Rao GS. The value of transmandibular approach to total maxillectomy in the management of T3-T4 carcinoma of the maxillary sinus. Eur Arch Oto-Rhino-Laryngol. 2010;267(6):951-954. doi:10.1007/s00405-009-1168-4
12. Homma A, Hayashi R, Matsuura K, et al. Lymph node metastasis in t4 maxillary sinus squamous cell carcinoma: incidence and treatment outcome. Ann Surg Oncol. 2014;21(5):1706-1710. doi:10.1245/s10 434-014-3544-6

13. Yang F, Bao Y, Zhou Z, Jin C, Fu D. Preoperative neutrophil-tolymphocyte ratio predicts malignancy and recurrence-free survival of solid pseudopapillary tumor of the pancreas. J Surg Oncol. 2019;120 (2):241-248. doi:10.1002/jso.25484

14. McDermott SM, Saunders ND, Schneider EB, et al. Neutrophil lymphocyte ratio and transarterial chemoembolization in neuroendocrine tumor metastases. J Surg Res. 2018;232:369-375. doi:10.1016/ j.jss.2018.06.058

15. Wang Y, Peng C, Cheng Z, et al. The prognostic significance of preoperative neutrophil-lymphocyte ratio in patients with hepatocellular carcinoma receiving hepatectomy: a systematic review and meta-analysis. International Journal of Surgery. 2018;55:73-80. doi:10.1016/j.ijsu.2018.05.022

16. Tsujita E, Ikeda Y, Kinjo N, et al. Postoperative neutrophil-tolymphocyte ratio as a predictor of long-term prognosis after pancreatectomy for pancreatic carcinoma: a retrospective analysis. Am Surg. 2017;83(6):610-616.

17. Yang T, Zhu J, Zhao L, et al. Lymphocyte to monocyte ratio and neutrophil to lymphocyte ratio are superior inflammation-based predictors of recurrence in patients with hepatocellular carcinoma after hepatic resection. J Surg Oncol. 2017;115(6):718-728. doi:10.1002/ jso.v115.6

18. Sato Y, Gonda K, Harada $\mathrm{M}$, et al. Increased neutrophil-tolymphocyte ratio is a novel marker for nutrition, inflammation and chemotherapy outcome in patients with locally advanced and metastatic esophageal squamous cell carcinoma. Biomed Rep. 2017;7 (1):79-84. doi:10.3892/br.2017.924

19. Hung HC, Lee JC, Cheng CH, et al. Impact of neutrophil to lymphocyte ratio on survival for hepatocellular carcinoma after curative resection. J Hepatobiliary Pancreat Sci. 2017;24(10):559-569. doi:10.1002/jhbp.498

20. Bilen MA, Dutcher GMA, Liu Y, et al. Association between pretreatment neutrophil-to-lymphocyte ratio and outcome of patients with metastatic renal-cell carcinoma treated with nivolumab. Clin Genitourin Cancer. 2018;16(3):e563-e575. doi:10.1016/j.clgc.2017.12.015

21. Galun D, Bogdanovic A, Djokic Kovac J, Bulajic P, Loncar Z, Zuvela M. Preoperative neutrophil-to-lymphocyte ratio as a prognostic predictor after curative-intent surgery for hepatocellular carcinoma: experience from a developing country. Cancer Manag Res. 2018;10:977-988. doi:10.2147/CMAR.S161398

22. Hu J, Wang N, Yang Y, et al. Diagnostic value of alpha-fetoprotein combined with neutrophil-to-lymphocyte ratio for hepatocellular carcinoma. BMC Gastroenterol. 2018;18(1):186. doi:10.1186/s1287 6-018-0908-6

23. Bakshi SS. Preoperative neutrophil-to-lymphocyte ratio predicts the prognosis of oral squamous cell carcinoma. J Oral Maxillofacial Surg. 2017;75(6):1093-1094. doi:10.1016/j.joms.2017.01.044

24. Chen MF, Tsai MS, Chen WC, Chen PT. Predictive value of the pretreatment neutrophil-to-lymphocyte ratio in head and neck squamous cell carcinoma. J Clin Med. 2018;7:10. doi:10.3390/jcm7010010

25. Getzler I, Bahouth Z, Nativ O, Rubinstein J, Halachmi S. Preoperative neutrophil to lymphocyte ratio improves recurrence prediction of non-muscle invasive bladder cancer. BMC Urol. 2018;18(1):90.

26. Lin AJ, Rao YJ, Chin RI, et al. Post-operative radiation effects on lymphopenia, neutrophil to lymphocyte ratio, and clinical outcomes in palatine tonsil cancers. Oral Oncol. 2018;86:1-7. doi:10.1016/j. oraloncology.2018.08.008

27. Chang X, Zhang F, Liu T, Wang W, Guo H. Neutrophil-tolymphocyte ratio as an independent predictor for survival in patients with localized clear cell renal cell carcinoma after radiofrequency ablation: a propensity score matching analysis. Int Urol Nephrol. 2017;49(6):967-974. doi:10.1007/s11255-017-1554-6 
28. Li SH, Wang QX, Yang ZY, et al. Prognostic value of the neutrophil-to-lymphocyte ratio for hepatocellular carcinoma patients with portal/hepatic vein tumor thrombosis. World $J$ Gastroenterol. 2017;23(17):3122-3132. doi:10.3748/wjg.v23.i17.3122

29. Okui M, Yamamichi T, Asakawa A, Harada M, Saito M, Horio H. Prognostic significance of neutrophil-lymphocyte ratios in large cell neuroendocrine carcinoma. Gen Thorac Cardiovasc Surg. 2017;65 (11):633-639. doi:10.1007/s11748-017-0804-y
30. Singh S, Himler J, Nagel CI, Resnick K. The prognostic value of baseline lymphocyte, neutrophil, and monocyte counts in locally advanced cervical carcinoma treated with radiation. Obstet Gynecol Int. 2017;2017:8584605. doi:10.1155/2017/8584605

31. Yoshida D, Minami K, Sugiyama M, et al. Prognostic impact of the neutrophil-to-lymphocyte ratio in stage I-II rectal cancer patients. J Surg Res. 2019;245:281-287. doi:10.1016/j.jss.2019.07.072

\section{Publish your work in this journal}

Cancer Management and Research is an international, peer-reviewed open access journal focusing on cancer research and the optimal use of preventative and integrated treatment interventions to achieve improved outcomes, enhanced survival and quality of life for the cancer patient.
The manuscript management system is completely online and includes a very quick and fair peer-review system, which is all easy to use. Visit http://www.dovepress.com/testimonials.php to read real quotes from published authors. 